\title{
Permian bryozoans from southern Spitsbergen and Bjørnøya. A review of bryozoans described by J. Malecki $(1968,1977)$
}

\author{
HANS A. NAKREM
}

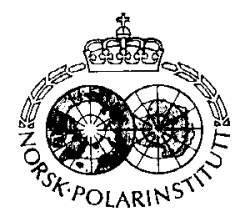

\begin{abstract}
Nakrem, H. A. 1988: Permian bryozoans from southern Spitsbergen and Bjørnøya. A review of bryozoans described by J. Malecki (1968, 1977). Polar Research 6, 113-121.

Bryozoans previously described by Malecki $(1968,1977)$ are revised and a full redescription is given of the timanodictyine cryptostome Gilmoropora heintzi (Malecki 1977), which was previously regarded as a trepostome. Ramipora hochstetteri Toula 1875, described as the fenestrate Septopora phyllata Malecki 1977 , is a senior synonym of some subsequently described ramiporid cystoporates. A revised and updated stratigraphical distribution is given for all species, and a table of registered material is presented for cach taxon.
\end{abstract}

Hans A. Nakrem, Continental Shelf and Petroleum Technology Research Institute Ltd., Håkon Magnussons gt. 1B, N-7001 Trondheim, Norway; September 1987 (revised January 1988).

Bryozoans rank among the most common fossil groups in the Permian deposits of Svalbard. Very little had been done to explore the biostratigraphical value of these fossils until a study was started by the author at the University of Oslo in 1985. The first step was to evaluate the relevant previous work, and the purpose of this paper is to review the bryozoans described by Malecki $(1968,1977)$ and to discuss some of the misinterpretations presented in these two papers.

Initially, Malecki's described material could not be found at Paleontologisk Museum, Oslo, but after requests to Dr. J. Malecki (Kraków, Poland) and to Prof. K. Birkenmajer (Warszawa, Poland), part of the material was returned to Paleontologisk Museum. Much of the material described and figured in the 1968 paper was originally numbered when collected, but the numbers were omitted in the paper. Some new acetate peels of the original material described in both papers have been prepared by the author. The remaining parts of the described and figured material have not been obtained, and are presumed lost.

The material was collected by Prof. S. Siedlecki in 1964 and 1965 in two areas of Svalbard: southernmost Spitsbergen and Bjørnøya (Malecki 1968, 1977; cf. Siedlecki 1964). As stated on the sample labels (e.g. A35214) some material was also collected by Prof. K. Birkenmajer in 1970 .
Table 2 lists all A-numbers, original and revised identifications, localities, stratigraphy and related information of Paleontologisk Museum, Oslo. The stratigraphical divisions given by Cutbill \& Challinor (1965) and Worsley \& Edwards (1976) have been followed.

\section{Order Cystoporata}

\section{Ramipora hochstetteri Toula 1875}

1875 Ramipora hochstetteri Toula 1875 ; p. 230 , PI. X, Figs. 1a, b.

1936 Ramipora hochstetteri Toula; Nikiforova, p. 127, Pl. 2, Figs. 7-10, Text-figs. 1, 2.

1977 Septopora phyllata Malecki; pp. 85-86, Pl. VII, Fig. 2, Text-fig. 2.

1983 Ramipora hochstetteri Toula; Utgaard in Boardman et al., p. 436 , Figs. $215,3 a-c$.

1986 Ramipora phyllata (Malecki); Morozova \& Kruchinina, p. 41.

1986 Ramipora fragilis Morozova; Morozova in Morozova \& Kruchinina, Pp. 42-43, Pl, 8, Figs. 2a-b, 3.

The large, well-preserved specimen is not a fenestrate as supposed by Malecki, but belongs to the cystoporate genus Ramipora, and was consequently referred to as Ramipora phyllata (Malecki) by Morozova \& Kruchinina (1986). The specimen has been closely reexamined (thin sections have not been prepared), and numerical measurements are as follows: 
No. of branches per $10 \mathrm{~mm}$ :

No. fenestrules per $10 \mathrm{~mm}$ :

No. zooecia per $5 \mathrm{~mm}$ :

Width of branch (mm):

Width of lateral branches:

Fenestrule length $(\mathrm{mm})$ :

Fenestrule width:

Zooecial aperture diameter:

These dimensions indicate the close resemblance to $R$. hochstetteri Toula of $R$. fragilis Morozova 1986 described from Novaya Zemlya (Upper Permian Ufimian and Kazanian Stages). The variation within all parameters is large enough to group all species within $R$. hochstetteri Toula. Therefore, $R$. phyllata (Malecki) and $R$. fragilis Morozova are regarded junior synonyms for $R$. hochstetteri Toula. $R$. lepida Morozova, described from Spitsbergen (Kapp Starostin Fm.), has significantly thinner branches and is therefore regarded as a distinct species.

Original PMO number: A32078, renumbered by Malecki A35219. Type locality: Oppgangsdalen, SW side of Miseryfjellet, Bjørnøya. Stratigraphical horizon: Upper Miseryfjellet Formation.

Ramipora cf. hochstetteri Toula 1875

1875 Ramipora hochstetteri Toula; p. 230, PI. X, Figs. La, b. 1936 Ramipora hochstetteri Toula; Nikiforova p. 127, PI. 2 Figs. 7-10, Text-figs. 1-2.

$1968 P$. sp. cf. russiensis Shul'ga-Nesterenko; Malecki p. 22, Pl. VII, Figs. 3, 4, 7, 8, 9.

Some specimens figured as Polypora sp. cf. russiensis are differently oriented sections of Rami-
New data

2.5-3.5

Malecki's data

$3.0-3.8$

10

$1.0-1.1$

$0.7-0.8$

$2.0-3.3$

$2.0-3.0$

0.15

3-4

$2-3$

10

$1.8-2.2$

$1.2-1.5$

$2.0-3.0$

$3.0-4.0$

0.2

pora cf. hochstetteri Toula 1875 . Locality and stratigraphical horizon are not given.

\section{Order Trepostomata}

Tabulipora siedleckii Malecki 1968

1968 Tabulipora siedleckii Malecki; pp. 13-21, Pl, I-V, VI, Figs. 6, 9, 10, Text-figs. 4-6, 8-14.

There are no comments on the systematic description given by Malecki for his new species. The material was originally not numbered, but the figured holotype (Pl. I, Fig. 1) has now been numbered A42258. Paratype, for sectioning: A42259. Locality: Tokrossøya, Sørkappland, western Spitsbergen. Stratigraphical horizon: lower member of the Tokrossøya beds, Upper Bryozoan Horizon (= lower part of the Tokrossøya Formation, a regional equivalent to the Kapp Starostin Formation, ?Artinskian-Ufimian age).

Remarks: Colony growth is discussed in the section on astogeny, but in the section on 'regeneration' some errors are present. On Pl. II, Figs 4,7 and 9 , the endozone is totally crushed. Malecki states: 'In the central part, the zooecial tubes have been pressed, the external zone was cracked, broken and damaged in parts . . . A flattened branch is illustrated in $\mathrm{pl}$. II, fig. 9. This flat-

Table 1. Micrometric comparison between similar species of Ramipara. $(R$. hochstetteri Toula has been re-evaluated from the type specimen (not thin sections) for this purpose.)

\begin{tabular}{lccccc}
\hline & $\mathrm{B} / 10$ & $\mathrm{~F} / 10$ & $\mathrm{Z} / 10$ & W-1.br. & W-2,br. \\
R. hochstetteri Toula & 2.3 & $2.2-2.4$ & $8-10$ & $1.0-1.1$ & $0.9-1.1$ \\
R. hochstetteri Toula; sensu Nikiforova 1936 & 3 & $1.5-2.0$ & $?$ & & \\
R. phyllata (Malecki) & $2.5-3.5$ & $3.5-3.8$ & 10 & $1.0-1.1$ & $0.7-0.8$ \\
R. lepida Morozova & $2-3$ & $2-3$ & $7-9$ & $0.5-0.6$ & $0.4-0.7$ \\
R. fragilis Morozova & $2-4$ & $2-3$ & $9-11$ & $0.9-1.0$ & $0.5-0.7$ \\
\hline
\end{tabular}

B/10: Branches per $10 \mathrm{~mm}$

$\mathrm{F} / 10$ : Fenestrules per $10 \mathrm{~mm}$

$\mathrm{Z} / 5$ : Zooecia per $5 \mathrm{~mm}$

W-1.br.: Width of main (1. order) branch

W-2.br.: Width of lateral (2, order) branch 
tening was observed along $12 \mathrm{~cm}$. and despite that free space was near the branch, it did not change in transverse section' ( $p$. 28). The flattening is ascribed to fused growth of branches during life. However, the crushing of the endozone of these colonies more probably occurred after death, as a reaction to excessive overburden and deep burial in sediment. It should be considered as a post mortem phenomenon.

Tabulipora greenlandensis Ross \& Ross 1962

1962 Tabulipora greenlandensis Ross \& Ross; p. 36, Pl. 10, Fig. 5; Pl. 11, Figs. 1-5.

1977 Tabulipora greenlandensis Ross \& Ross; Malecki, pp. 8081, PI. III, Figs. 1a-c.

1986 Tabulipora greenlandensis Ross \& Ross; Morozova \& Kruchinina, p. 45, Pl .10, Figs. 1a-c.

The original material is missing. It seems possible that the described specimens are of Tabulipora siedleckii Malecki 1968. The dimensions (including diameter of colony) may differ slightly, but as Malecki (1968) states, those 'features are not characteristic for the species of the genus Tabulipora'. Locality/stratigraphy: as for Stenopora jungersenensis.

?Tabulipora cf. gigantea (Ross \& Ross 1962)

1962 Rhombotrypella cf. gigantea Ross \& Ross; p. 29, PI. 5, Figs. 1, 3-5.

1977 Rhombotrypella cf. gigantea Ross \& Ross; Malecki, pp. 81-82, PI. IV, Figs. 1a-e.

Malecki's specimen is probably allied to the species described by Ross \& Ross (1962) from Greenland, but should probably be referred to as Tabulipora cf. gigantea (Ross \& Ross) based on the very beaded exozonal walls and the large number of perforated and complete diaphragms. The problem of distinguishing between the genera Tabulipora and Rhombotrypella is being studied by L. Madsen (pers. comm. 1986). Locality: Sandhamna and $\varnothing$ yrlandet, southern Spitsbergen. Stratigraphical horizon: Tokross $\varnothing$ ya Formation. Available material: one peel, A35211 (Pl. IV, Fig. 1d).

Rhombotrypella alfredensis Morozova 1986 non 1939 Rhombotrypella composita Nikiforova; pp. 80-81, 95, Pl. 2, Fig. 10-11; Pl. 3, Figs. 1-6.

non 1961 Rhombotrypella composita Nikiforova; Trizna \& Klautsan, pp. 400-401, Pl. 5, Figs. 1-4.

1962 Rhombotrypella cf. composita Nikiforova; Ross \& Ross, pp. 30-31, Pl. 3, Fig. 3; Pl. 4, Fig. 4; Pl. 5, Fig. 2.

1977 Rhombotrypella cf. composita Nikiforova; Malecki, p. 82, Pl. V, Figs. la-b.

1986 Rhombotrypella alfredensis Morozova in Morozova \& Kruchinina, p. 49, Pl. 13, Figs. 1a-c.
The figured thin section is missing, but the host rock was found, and new acetate peels have been prepared. After close reexamination of these new peels, this species is considered to belong to Rhombotrypella alfredensis Morozova 1986. The important features in Malecki's material and the subsequently peeled colonies are the large and closely spaced zooecial apertures, the large acanthostyles and the colony width, all being more delicate in $R$. composita in comparison to $R$. alfredensis.

The locality on the rock sample (Herwighamna, Bjørnøya) does not fit in with the one given by Malecki ( $\varnothing$ yrlandsodden, southern Spitsbergen). Recent sampling from Herwighamna from identical lithologies (sandy bioclastic limestone) has provided supplementary specimens, and the correct locality of Malecki's material is considered to be Herwighamna.

Original number: A32068, renumbered by Malecki 35212. Rhombotrypella alfredensis Morozova was originally described from Bjørnøya (Alfredfjellet), from the basal Miseryfjellet Formation.

Stenopora dickinsi Ross 1963

1963 Stenopora dickinsi Ross; pp. 73-75, Pl. 8, Figs. 1-3, 5-8; Pl. 1-5, 7-9.

non 1968 Stenopora dickinsi Ross; Malecki, p. 22, Pl. VII, Figs. $1,2$.

1977 Stenopora dickinsi Ross; Malecki, pp. 79-80, PI. II, Figs. 1a, b.

The described and figured material is missing, and no further information on the identification is available. Locality: Herwighamna, Bjørnøya. Stratigraphical horizon: Lower Miseryfjellet Formation.

Stenopora jungersenensis Ross \& Ross 1962

1962 Stenopora jungersenensis Ross \& Ross; pp. 44-46, P1. 12. Figs. 1, 2, 4; Pl. 13, Fig. 2; Pl. 17, Fig. 7.

1977 Stenopora jungersenensis Ross \& Ross; Malecki, p. 80, Pl. II, Figs. 2a-d.

The original material is missing. According to Malecki's figures (e.g. Pl. II, Fig. 1d) which show the presence of numerous angular exilazooecia and the apparent absence of small acanthostyles (distinct microacanthostyles), the described species may belong to the genus Dyscritella, but further identification is impossible. For numerical measurements, see Malecki (1977). Localities: Herwighamna, Bjørnøya and Bellsund, Spitsbergen. Stratigraphical horizon: Lower 

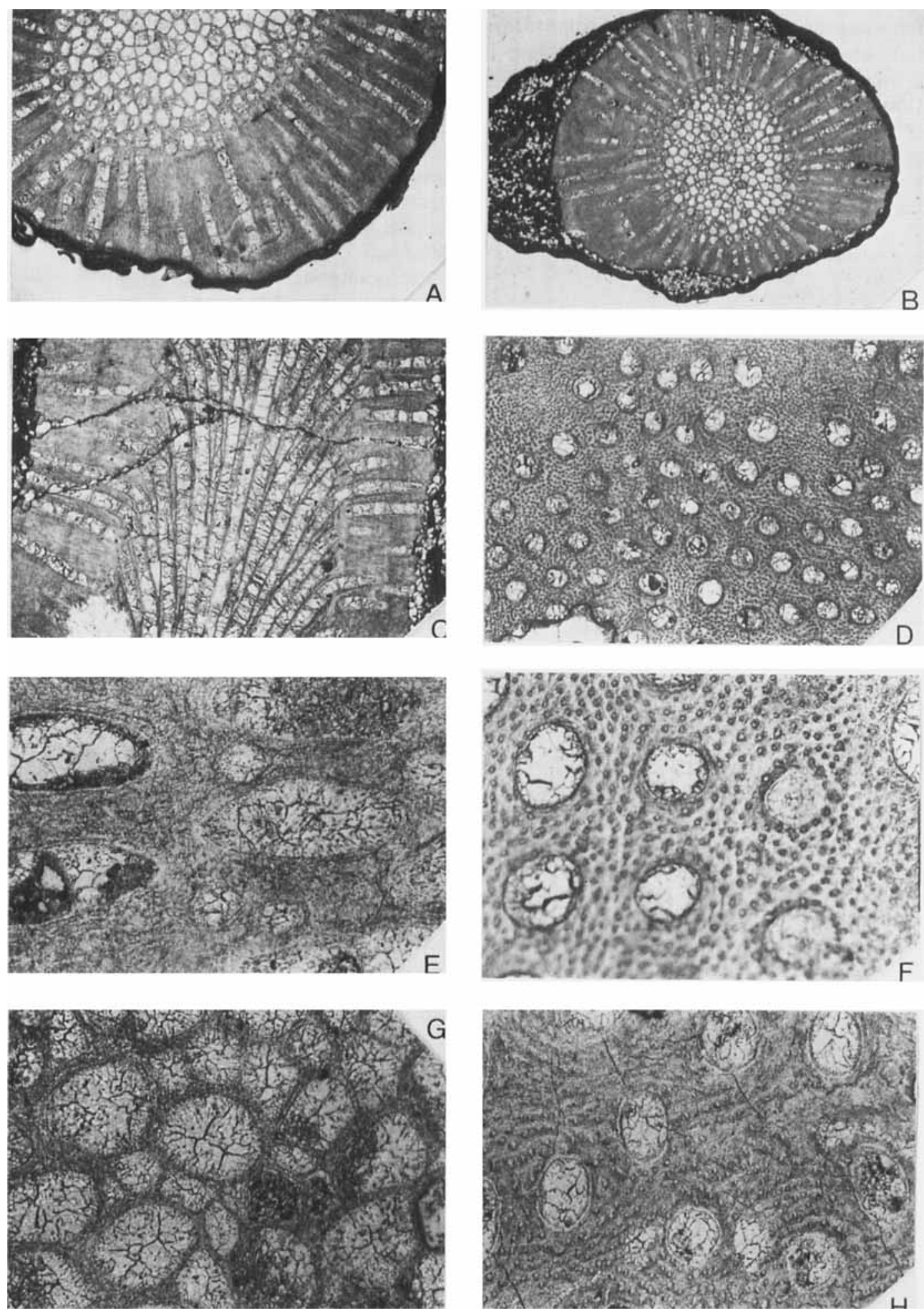
Miseryfjellet Formation and Kapp Starostin Formation.

Dyscritella? lyndoni (Ross 1963)

1963 Stenopora lyndoni Ross; pp. 76-77, Pl. 11, Figs. 1-3, 6-10. 1968 Stenopora lyndoni Ross; Malecki, p. 21, PI. VI, Figs. 1-5, $7,8,11$.

Malecki's thin sections/acetate peels have not been found. Of taxonomic importance, evident from Malecki's description and figures, is the absence of small acanthostyles and the presence of numerous exilazooecia ( $>10$ per zooecial aperture in the thick-walled exozone). Both features are lacking in Stenopora (Astrova 1978). Exilazooecia are angular and isolate the zooecial tubes. These factors indicate that the described specimens should be included in the genus Dyscritella. The species designation is, however, unclear.

Malecki interpreted as regenerations some well figured pressure dissolutions (Pl. II, Figs. 1, 2, 4, 7, 10; Pl. VI, Fig. 2). When carbonate fragments and skeletal parts make contact under stress (during burial and diagenesis) solution and removal of carbonate often occurs, and the fragments become significantly distorted and reduced in size. In these grain-to-grain contacts styloliths may develop (Bathurst 1971), like those which are seen in Malecki's figures. Locality: Tokrossøya, southern Spitsbergen. Stratigraphic horizon: Lower Tokrossøya Formation.

Dyscritella dickinsi (Ross 1963)

1963 Stenopora dickinsi Ross; pp. 73-75, Pl. 8, Figs. 1-3, 58; Pl. 9, Figs. 1-5, 7-9.

1968 Stenopora dickinsi Ross; Malecki, p. 22. PI. VII, Figs. 1, 2.

?1970 Dyscritella parallela Morozova; p. 110, PI. XVI, Fig. 2.

Based on the nature and width of the exozone, dimensions and ratio of exozone to branch width and the obvious lack of small acanthostyles, this species should be referred to the genus Dyscritella. Apparently parallel endozonal zooecia indicate a close resemblance to $D$. parallela Morozova 1970, but Malecki's material has not been located, and the additional sections required to corroborate this assignment are unavailable. Locality: Tokrossøya. Stratigraphical horizon: Tokrossøya Formation.

Dyscritella bogatensis Morozova 1970

1970 Dyscritella bogatensis Morozova; p. 108, Pl. XV, Fig. 1. 1977 Dyscritella bogatensis Morozova; Malecki, p. 83, Pl. VI, Figs. 1a-d.

1986 Dyscritella bogatensis Morozova; Gilmour \& Walker, p. 200, Figs. 7d-e, g-h.

1986 Dyscritella maleckii Morozova; Morozova in Morozova \& Kruchinina, p. 55, Pl. 16, Figs. 2a-c.

The specimen described by Malecki is placed in synonym by Morozova (in Morozova \& Kruchinina 1986) with her new species $D$. maleckii. More specimens have been sectioned by the present author, and very close similarities between $D$. bogatensis and $D$. maleckii are obvious. Morozova distinguishes $D$. maleckii by the lack of parallel endozonal zooecia and absence of protruding acanthostyles. However, the protruding acanthostyles (Malecki p. 83) and parallel zooecia in the endozone (Malecki Pl. VI, Fig. 1d) are both present in $D$. maleckii. The new species $D$. maleckii should therefore be rejected, and $D$. bogatensis is regarded as the valid determination of the specimens described by Malecki. The localities given by Malecki (Stjernøya and $\varnothing y r-$ landet, southern Spitsbergen) do not fit in with those on the rock samples, which are marked Kapp Olsen, Bjørnøya. The lithology matches very well with that of the other Kapp Olsen samples, namely a spiculitic shale horizon from the lowermost Miseryfjellet Formation. The material was originally numbered A32111, renumbered by Malecki A35213.

Fig. 1. Gilmoropora heintzi (Malecki)

A: Transverse section, 10x. PMO A 32111t.

B: Transverse section, $7 \times$. PMO A $32111 \mathrm{v}$.

C: Longitudinal section, $10 \times$. PMO A 32111 .

D: Tangential section, showing zooecial apertures, and maculum (upper left), 23×. PMO A 32111s.

E: Oblique longitudinal section, showing large autozooecial tubes (oval) and smaller fossazooecia (circular), 55×. PMO A 42257.

F: Tangential section, showing autozooecial apertures and capillaries, 51×. PMO A 32111s.

G: Deep tangential section, showing fossazooccia arranged around autozooecia, 56x. PMO A 42257.

$\mathrm{H}$ : Tangential section, showing light calcareous zooecial lining around zooecial apertures, and capillaries arranged in rows, $50 \times$. PMO A 32111s.

All illustrations were made from acetate peels, using a Leitz Ortholux/Vario-Orthomat. Material deposited at Paleontologisk Museum, Oslo. 


\section{Order Cryptostomata}

Streblascopora fasciculata (Bassler 1929)

?1894 Fistulipora permiana Nechaev; p. 103, Pl. 1, Figs. 43bd.

1929 Streblascopora fasciculata Bassler; p. 66, Pl. 139, Figs. 4-5.

1965 Streblascopora fasciculato (Bassler); Shishova, p. 58, Pl. 6, Fig. 2.

1970 Streblascoporu fasciculata (Bassler); Morozova, pp. 150151, PI. 27, Fig. 3.

1971 Streblotrypa (Streblascopora) fasciculata (Bassler); Termier \& Termier, Pl. 9, Fig. 6.

1977 Streblotrypa fasciculata Bassler; Malecki, p. 84, P1. 5, Figs. 2a-d.

1981 Strebluscopora fasciculata (Bassler); Morozova, p. 44, Pl. 11, Fig. 2.

1983 Streblascopora fasciculata (Bassler); Yang \& Lu, pp. 289 290. P1. 7, Figs. 10-15.

1985 Streblascopora fasciculata (Bassler); Gorjunova, pp. 129 130, Pl. 16, Fig. 2.

Malecki used the generic name Streblotrypa in the text (pp. 83-84) and Streblascopora in the plate description. Streblascopora is distinguished from Streblotrypa in exhibiting a well-defined axial bundle of zooecia (see Blake 1983 who reduces Streblascopora to a subgenus of Streblotrypa). The figured material (PI. V, Figs. 2a-d) displays the axial bundle, and should thus be assigned to Streblascopora fasciculata (Bassler). Morphological characters have been remeasured, and Malecki's specific designation is regarded as correct.

In the description the material is labelled Kapp Olsen, Bjørnøya. Stratigraphical horizon: spirifer Limestone (Artinskian-Upper Permian). The label on the specimen gives the locality as Polakkfjellet (southern Spitsbergen, collected by $\mathrm{K}$. Birkenmajer, 1970), whereas in Paleontologisk Museum's file the material is labelled Bellsund, Diabasodden (?Diabasbukta), 'Cancrinella Limestone'. The latter fits very well with the light grey dolomitic matrix and contrasts with the spiculitic nature of the Kapp Olsen strata. The 'Cancrinella Limestone' is correlated (e.g. Birkenmajer \& Logan 1967) with 'Cora Limestone' (Hambergfjellet Formation) on Bjørnøya, and upper 'Cyathophyllum Limestone' and upper 'Wordiekammen Limestone' on Spitsbergen. In modern stratigraphical usage (Cutbill \& Challinor 1965) the 'Cancrinella Limestone' is within the Reinodden/Treskelodden Fm. correlative to the Tyrrellfjellet $\mathrm{Mb}$. of the Nordenskiöldbreen Formation (?Asselian-Sakmarian age) on northern Spitsbergen. This makes it considerably older than the Upper Permian age implied by Malecki.
It also represents a significantly older record of Streblascopora fasciculata than has previously been reported. The material was originally numbered A32083, renumbered by Malecki as A35214.

\section{Suborder Timanodictyina Morozova 1966 \\ Family GIRTYPOROIDEA Morozova 1966}

Gilmoropora heintzi (Malecki 1977). Figs. 1A-H. 1977 Hinganella heintzi Malecki; pp. 78-79, Pl. I. Figs. 1a-e. 1986 Gilmoropora unica Morozova in Morozova \& Kruchinina, pp. 123-124, Pl. 48, Figs. 2a-c.

Description. Colony ramose and dichotomously branched, branches circular or slightly oval in the transverse section (Fig. 1A, B). Circular branch diameter up to $10.3 \mathrm{~mm}$, oval branches $8.50 \times 5.60 \mathrm{~mm}$. Broken fragments indicate the existence of even thicker branched colonies. Zooarial surface slightly tuberculated, with angular ridges between zooecial apertures. Exozone maximum width $2.4 \mathrm{~mm}$, endozone maximum $5.5 \mathrm{~mm}$. The ratio of exozone radius to zooarium diameter is fairly constant at $1: 3.5$ (7 zooaria from 3 localities taken into consideration). Zooecia tubular, rounded in exozone, polygonal in endozone. Zooecial tubes are arranged almost parallel in endozone, and bend sharply outwards when approaching the exozone (Fig. 1C). In the outer part of the endozone and through the exozone there are continuous diaphragms, irregularly distributed, usually $6-8$ per zooecial tube (average 5 per $\mathrm{mm}$, Fig. 1C). Zooecial walls in the endozone display a granular microstructure, thickness 0.02-0.03, up to 0.05 in budding centres. Exozonal walls are pierced by numerous stenostyles ('capillaries' of Soviet workers), diameter $0.01-0.02 \mathrm{~mm}$, arranged parallel with zooecial tubes, irregularly distributed around zooecial apertures (Fig, 1F, H). Thickness of exozonal wall (= distance between adjacent zooecial apertures on the tangential section) $0.15-0.16 \mathrm{~mm}$. Maculae of varying size irregularly distributed, devoid of zooecial apertures (Fig. 1D). Zooecial apertures arranged in oblique rows; their shape is circular or slightly oval with a clear zooecial lining visible in the tangential section. Diameter of circular aperture $0.17-0.22 \mathrm{~mm}$, oval dimension $0.16 \times 0.19-0.18 \times 0.23$. Number of zooecia per $2 \mathrm{~mm}$ is $5-6$, some areas with higher density of zooecial apertures. Fossazooecia 


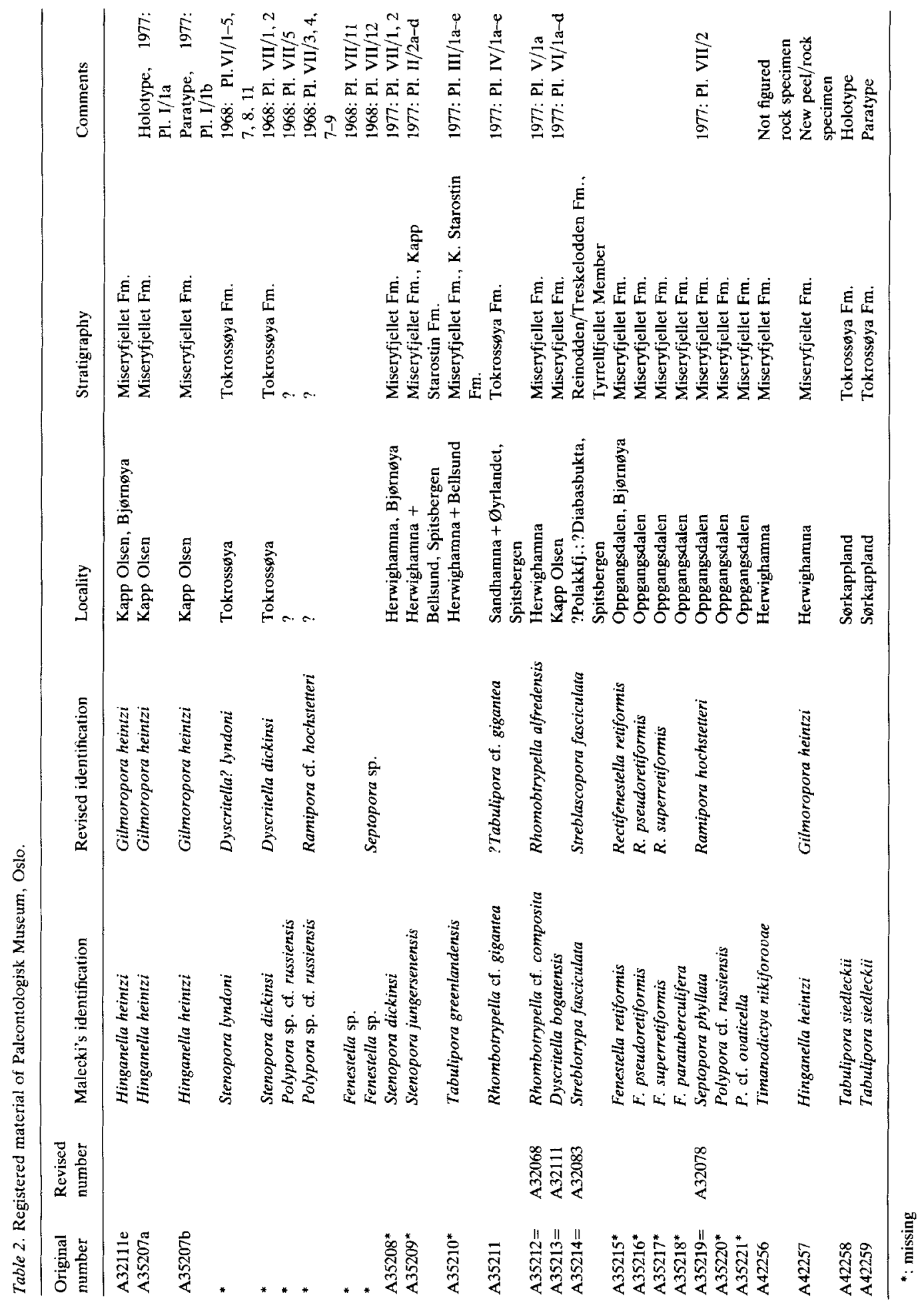


('mesopores' sensu Malecki) are visible in both the longitudinal and tangential section, their diameter being $0.10-0.14 \mathrm{~mm}$ (Fig. 1E, G). The zooecial tubes are wrinkled, and appear in different diameters in the oblique longitudinal section (Fig. 1E).

Remarks. - Malecki assigned his new species to the trepostome genus Hinganella of the family Eridotrypellidae Morozova 1960. In the generic description of Hinganella, Malecki refers to Romanchuk (1967) and accepts that acanthostyles (acanthopores sensu Malecki) should not be present (p. 78). In the species description of Hinganella heintzi Malecki states that 'the wide spaces among the apertures are pierced by numerous mesopores and acanthopores, protruding on the zooarium surface' (p. 79). Also 'the acanthopores of $H$. heintzi are poorly outlined ...' (p. 79). Thus, in his opinion acanthostyles are present, and his specimens cannot be included in the genus Hinganella.

New acetate peels have been prepared from Malecki's material and from recently collected material from Bjørnøya. Close reexamination of many zooaria has revealed features that enable a major taxonomic reassignment of the species from the Trepostomata to the cryptostome suborder Timanodictyina Morozova 1966 and family Girtyporidae Morozova 1966.

Recently Morozova \& Kruchinina (1986) described a rich bryozoan fauna from Svalbard ('Spitsbergen Archipelago'), including a new genus Gilmoropora, with one species Gilmoropora unica, which shows the same morphological characters as Hinganella heintzi Malecki. The type locality of these two species is also identical. It is therefore proposed that Hinganella heintzi Malecki and the species described by Morozova \& Kruchinina should correctly be named Gilmoropora heintzi (Malecki 1977). Morozova \& Kruchinina (1986) refer to Malecki's work, renaming his species Neoeridotrypella heintzi (Malecki), even though Hinganella heintzi Malecki is listed in their Table 3 under its original name.

Distribution: Upper Permian, Ufimian, Miseryfjellet Formation ('Starostinsk Group' used by Morozova \& Kruchinina 1986), common within the lowermost $15 \mathrm{~m}$, less frequent in the uppermost part of the formation. Type locality: Nordkapp, Bjørnøya. More than 20 zooaria collected on Bjørnøya (Nordkapp, Kapp Olsen,
Herwighamna, Hambergfjellet and Miseryfjellet).

Malecki's material was originally numbered A32111a-e, renumbered by Malecki as A35207ac. Holotype: A35207a (rock specimen, PI. I, Fig. 1a). Paratypes: A35207b (acetate peel) and A32111e (rock specimen).

\section{Family TIMANODICTYOIDEA Morozova 1966}

Timanodictya nikiforovae Morozova

1966 Timanodictya nikiforovae Morozova; p. 35, Pl. V, Fig. 1. 1970 Timanodictya nikiforovae Morozova; Morozova, p. 244, Pl. LIX, Fig. 1.

1977 Timanodictya nikiforovae Morozova; Malecki, p. 86, PI. VII, Figs. 1a-c.

1986 Timanodictya nikiforovae Morozova; Morozova \& Kruchinina, p. 121, Pl. XLVII, Fig. 1.

No further comments can be given on the description and the identification. Malecki's original thin sections are missing, but several fragments have been observed in the rock samples from Herwighamna and Kapp Olsen, Bjørnøya. The stratigraphical horizon is the lowermost Miseryfjellet Formation. A previously unnumbered piece from Malecki's collection which is typical of Timanodictya nikiforovae is A42256.

\section{Order Fenestrata}

Fenestella sp.

1968 Fenestella sp. Malecki; Pl. VII, Fig. 11.

Not mentioned by Malecki in his text. The specimen is missing, and no further information is available.

Septopora sp.

1968 Fenestella sp. Malecki; Pl. VII, Fig. 12.

Not mentioned by Malecki in his text. The specimen is missing, but from the illustration it is possible to identify it as Septopora sp., which has two rows of zooecia, both on the main branches and on the anastomosing side branches.

Polypora sp. cf. russiensis Shul'ga-Nesterenko 1941

1941 Polypora russiensis Shul'ga-Nesterenko; p. 158, 159, 239, 240, Pl. 42, Fig. 4, Text-fig. 120.

1962 Polypora cf. russiensis Ross \& Ross; p. 53, P1. 15, Fig. 6; Pl. 17, Fig. 1.

1968 Polypora sp. cf. russiensis Malecki; p. 22, PI. VII, Fig. 5., non Figs. 3, 4, 7-9.

This species was compared with and found to resemble a species described by Ross \& Ross (1963) as Polypora cf. russienis. As the figured specimens are not numbered and the original slide has not been found, a re-evaluation is impossible. 
Rectifenestella retiformis (Schlotheim 1816) R. pseudoretiformis (Morozova 1970)

R. superretiformis Romanchuk 1970

Fenestella paratuberculifera Yang \& Lu 1962

A35215

A35216

A 35217

A35218

Polypora cf. russiensis Shul'ga-Nesterenko 1941 A35220

Polypora cf. ovaticella Shul'ga-Nesterenko 1941 A35221

None of these species (Malecki 1977) are figured, and the material is missing. No further comments can thus be made. Locality: Oppgangsdalen, SW side of Miseryfjellet. Stratigraphic horizon: Miseryfjellet Formation.

Acknowledgements. - The present work is part of a doctorate study carried out at the University of Oslo, financed by Institutt for Kontinentalsokkelunders økelser (IKU), Trondheim. I wish to thank Dr. P. D. Taylor, British Museum (Natural History), London, for giving valuable scientific comments and making grammatical improvements, Prof. K. Birkenmajer, Warszawa, for helping me to trace Dr. Malecki's bryozoan material and Prof. N. Spjeldnæs, University of Oslo, for arranging a loan of the type specimen of Ramipora hochstetteri Toula from Naturhistorisches Museum, Vienna. Thanks are also due to Atle Mørk, IKU, Trondheim, for introducing me to the geology of Svalbard.

\section{References}

Astrova, G. G. 1978: The history of development, system and phylogeny of the Bryozoa, order Trepostomata. Akad. Nauk. SSSR 169. $240 \mathrm{pp}$

Bassler, R. S. 1929: The Permian Bryozoa of Timor. Pp. 37-90 in Paläontologie von Timor 16 (28).

Bathurst, R. G. C. 1971: Carbonate sediments and their diagenesis. Developments in sedimentology 12 (2. ed.). 658 pp.

Birkenmajer, K. \& Logan, A. 1967: On the fauna and age of the Cancrinella Limestone (Permian) at Kopernikusfjellet, Vestspitsbergen. Nor. Polarinst. Årbok. 1967, 28-45.

Blake, D. L. 1983: The Suborder Rhabdomesina. Pp. 530-616 in Treatise on invertebrate paleontology. Pt. G. Bryozoa. I. Geol. Soc. Am. and Univ. Kansas.

Boardman, R. S., Cheetham, A. H., Blake, D. B., Utgaard, J., Karklins, O. L., Cook, P. L., Sandberg, P. A. Lutaud, G. \& Wood, T. S. 1983: Treatise on invertebrate paleontology, Part $G$, bryozoa (revised). Geol. Soc. Am. and Univ. Kansas. $625 \mathrm{pp}$.

Cutbill, J. L. \& Challinor, A. 1965: Revision of the stratigraphical scheme for the Carboniferous and Permian rocks of Spitsbergen and Bjørnøya. Geol. Mag. 102, 418-439.

Gilmour, E. H. \& Walker, R. C. 1986: Bryozoans from the Phosphoria Formation (Permian), southeastern Idaho. Contr. Geol., Univ. Wyoming 24 (2), 191-209.

Gorjunova, R. V. 1985: Morphology, systematics and phylogeny of Bryozoa (Order Rhabdomesida). Trudy Pal. Inst. Akad. Nauk USSR 208. 152 pp. (in Russian).

Malecki, J. 1968: Permian bryozoans from the Tokrossøya beds, Sørkappland, Vestspitsbergen. Stud. Geol. Polon. 21, 7-32.

Malecki, J, 1977: Permian bryozoans from southern Spitsbergen and Bjørnøya (Svalbard). Stud. Geol. Polon. 51, 75-87.

Morozova, I. P. 1960: The family Eridotrypellidae fam. nov. P. 65 in Fundamentals of Palaeontology. Bryozoans and brachiopods. Akad. Nauk. USSR (in Russian)

Morozova, I. P. 1966: A new suborder of late Palaeozoic bryozoans of the order Cryptostomata. Internat. Geology Rev. 9 (2), 186-194. (Transl. from Paleont. Zh. 1966 (2), 33-41.) Morozova, I. P. 1970: Late Permian Bryozoans. Trudy Pal. Inst. 122. Akad. Nauk., Moscow. 314 pp. (English transl. 1985).

Morozova, I. P. 1981: Late Paleozoic bryozoans from the North East USSR. Trudy Pal. Inst. 188. Akad. Nauk., Moscow. 119 pp. (in Russian).

Morozova, I. P. \& Kruchinina, O. N. 1986: The Permian bryozoans of the Arctic Region (western Sector). Akad. Nauk., Moscow. 144 pp. (English transl. 1986).

Nechaev, A. V. 1894: The fauna of the Permian deposits of the eastern margin of European Russia. Trudy Obshch. Estest. imp. Kazan. Univ. 27 (4). 515 pp. (in Russian).

Nikiforova, A. I. 1936: Some Early Permian bryozoans from Novaya Zemlya and Spitsbergen. Trudy arkt. nauchno-issled. Inst. 58, 113-141. (in Russian, Engl. summary).

Nikiforova, A. I. 1939: New species of late Palaeozoic bryozoans from the pre-montane belt of Bashkiria. Trudy neft. geol.-razv. Inst. Ser. A 115, 70-101 (in Russian, Engl. summary).

Romanchuk, T. V. 1967: New bryozoans of the order Trepostomata from the Upper Permian sequence of the Khabarovsk region. Paleont. Journal 1967 (2), 59-63. (Transl. from Paleont. Zh. 1967 (2), 69-73.)

Romanchuk, T. V. 1970: The first discoveries of bryozoans in the Upper Permian sequence of the Dzhady Range. Pp. 8186 in Novye vidy paleozoiskikh mshanok $i$ korallov (New species of paleozoic Bryozoa and Corals). Nauka Press (in Russian).

Ross, J. R. P. 1963: Lower Permian Bryozoa from Western Australia. Palaeontology 6, 70-82.

Ross, J. R. P. \& Ross, C. A. 1962: Faunas and correlation of the late Paleozoic rocks of Northeast Greenland. Pt. IV, Bryozoa. Medd. Gronl. 167 (7). 85 pp.

Schlotheim, E. F. 1816: Beiträge zur Naturgeschichte der Verstein etc. Denkschr. Akad. Wiss. München, 1816-1817, 4. $437 \mathrm{pp}$.

Siedlecki, S. 1964: Some remarks on the reconnaissance boat trip around Sørkapplandet to Kvalvågen, Vestspitsbergen. Stud. Geol. Polon. 11, 28-37.

Shishova, N. A. 1965: The systematic position and scope of the Family Hyphasmoporidae. Internat. Geology Rev. 7(10), 1814-1818. (Transl. from Paleont. Zh. 1965 (3), 52-57.)

Shul'ga-Nesterenko, M. I. 1941: Lower Permian Bryozoa of the Urals. Trudy Pal. Inst. Akad. Nauk. USSR 5 (1). 276 pp. (in Russian, Engl. summary).

Termier, H. \& Termier, G. 1971: Bryozoaires du paléozoique supérieur de l'Afghanistan. Docum. Lab. Geol. Fac. Sci. Lyon $47.52 \mathrm{pp}$.

Toula, F. 1875: Permo-Carbon-Fossilen von der Westküste von Spitsbergen. N. Jahrb. Min. Geol. Pal. 1875, 225-264.

Trizna, V. B. \& Klautsan, R. A. 1961: Bryozoans of the Artinskian Stage of the Ufa Plateau and their role in the stratigraphy of this stage in the Ural Region. Trudy uses. nauchno-issled. geol.-razv. Inst. 179, 331-453 (in Russian).

Worsley, D. \& Edwards, M. B. 1976: The Upper Palaeozoic succession of Bjørnøya. Nor. Polarinst. Arbok 1974, 3-34.

Yang, J. Z. \& Lu, L. H. 1962: The Paleozoic bryozoa from Mt. Qilian (Chilian). In Contributions to the geology of Mt. Qilian (Chilian) 4 (5). $190 \mathrm{pp}$. (in Chinese).

Yang, J. Z. \& Lu, L. H. 1983: Upper Carboniferous and Lower Permian bryozoans from Kalpin of Western Xinjiang. Paleontol. Carthayana 1, 259-317. 
